\title{
Position of Vietnam, Indonesia, and Malaysia in the Competition for Attracting FDI
}

\author{
Inna Andronova \\ Department of International Economic Relations, Economic \\ Faculty \\ People's Friendship University of Russia \\ Moscow, Russia \\ aiv1207@mail.ru \\ Olga Digilina \\ Department of Political Economy, Faculty of Economics \\ People's Friendship University of Russia \\ Moscow, Russia \\ o.b.digilina@mail.ru
}

\author{
Nikolay Gusakov \\ Department of International Economic Relations, Economic \\ Faculty \\ People's Friendship University of Russia \\ Moscow, Russia \\ gnp45@mail.ru
}

Nataliya Dyuzheva

Department of International Economic Relations, Economic Faculty

People's Friendship University of Russia

Moscow, Russia

dioujeva@yandex.ru

\author{
Nadezhda Kuchma \\ International Institute of Asian, African \& Latin American Studies \\ People's Friendship University of Russia \\ Moscow, Russia \\ kuchma_ns@pfur.ru
}

\begin{abstract}
Features of modern world development are associated with a changing role of developing countries in the competition for foreign direct investment. This article shows that the transformation of China's domestic policy and its transformation into a new regional leader in Asia has led to a change in the position of Vietnam, Malaysia, and Indonesia as recipients of foreign direct investment. Characteristics of China's economic development in recent years, namely the high growth rate of urbanization, "building a middle-class society" and the elimination of rural poverty, fundamental changes in environmental policy at the state level, the introduction of universal modernization of production, and so on - all this has led to an increase in cost placement of value chains in China. The purpose of this article is to show how Vietnam, Indonesia, and Malaysia has become the leading recipients of foreign direct investment in Southeast Asia. The research methodology is based on the principles of system analysis and an interdisciplinary system approach. To achieve this goal, the study used empirical methods (collection, study, and comparison of data), methods of comparative analysis and generalization of statistical data, principles of formal logic. As the result of the research, following the successful example of China in adapting conditions for foreign direct investment, Vietnam and, to a lesser extent, Malaysia are ahead of most other Asian countries because it has always adhered to an export-oriented growth strategy, but
\end{abstract}

Indonesia was not able to respond in a timely manner to the changing economic landscape.

Keywords: FDIs, economic growth, value chains, China, Vietnam, Indonesia, Malaysia, Southeast Asia

\section{INTRODUCTION}

Southeast Asia has become one of the thriving emerging markets that has welcomed FDI as part of its export-oriented development strategy. As a result, its share in both FDI inflows in emerging markets and world exports grew rapidly between currency adjustments after the signing of the Plaza Accord agreement between the governments of France, Germany, Japan, the United States and the United Kingdom on the depreciation of the United States dollar against the Japanese yen and the German brand through intervention in foreign exchange markets in 1985 and the outbreak of the Asian financial crisis in 1997. ASEAN member countries managed to maintain and even slightly increase their share of FDI at a time when emerging market economies around the world began to take a more liberal approach and actively compete for free FDI (including the closest neighbors of Southeast Asia - China and India), however, this was not 
comparative analysis and generalization of statistical data, principles of formal logic. region's economic growth rates (including the reasons for this lie in the failures of economic reforms in almost all countries of Southeast Asia).

For 30 years, China has turned from an almost completely closed economy into the second largest recipient country of FDI. It was FDI that played a key role in China's fast-growing export sector: foreign firms invested heavily in China to maximize the benefits of the favorable investment climate they created, cheap labor, access to resources, and the country's logistic location. More than half of Chinese exports are currently produced by foreign firms, and the bulk of this export is in assembly trade, when foreign firms deliver parts to China for final assembly and subsequent re-export. The use of such a mechanism by foreign companies allowed China to receive the necessary impetus for economic growth and, accordingly, the country's share in world exports.

Economic successes led to the beginning of the internal transformations that took place in China over the past decade, caused conceptual changes in the characteristics of direct foreign investment: high urbanization growth rates, "building a middle-class society" and the elimination of rural poverty, fundamental changes in environmental policy at the state level , the introduction of widespread modernization of production, and so on - all this provoked an increase in the cost of placing chains present value in China. This is what has allowed Vietnam, Indonesia and Malaysia to gain new competitive advantages and also become the leading recipients of foreign direct investment in Southeast Asia.

\section{LITERATURE REVIEW AND RESEARCH METHODS}

The basis of this study is the statistics of the World Bank, OECD, etc., as well as government reports of China, Vietnam, Malaysia, Indonesia on the amount and structure of FDI.

In addition to statistics and official documents, YP works were used to analyze structural changes in the PRC. Tian, W., Yu, M., Zhang, F [1], S. Gusarova [], Wu [3], who managed to demonstrate fundamental shifts in the current economic policy of China, as well as give first assessments of the consequences of the US-Chinese confrontation.

Features of the formation of investment attractiveness and attracting foreign direct investment in Vietnam, Malaysia and Indonesia were analyzed by different researchers. Thus, the process of creating an environment attractive to foreign capital was analyzed in the works of such researchers as Nguyen Nguyen [4], [5] Nguyen, D.T \& Yamauchi, F et al.[6], Xuan $\&$ Xing [7]. Research on the development of the investment potential of Malaysia was conducted by G. Kostyunina \& V. Baronov [8], Y.Chai [9]. An analysis of the economic development of Indonesia and its place in the global economy was carried out by Suyanto, R. Salim, H. Bloch [10], M. Y. Kadir \& A. Murrey [11].

The research methodology is based on the principles of system analysis and an interdisciplinary system approach. To achieve this goal, the study used empirical methods (collection, study, and comparison of data), methods of

\section{RESULTS AND DISCUSSION}

\section{A. Features of China's policy change in attracting FDI}

Since 2013, the PRC has begun to create an alternative model of international economic cooperation, which offers the participating countries conceptually different forms of interaction with each other, and should also make the PRC an independent and independent actor from the West.[1] The main difference of the proposed interaction model is that it is China that acts as the "center of attraction", which assumes all obligations to create an effective interaction infrastructure

- to create a global interaction platform, which links together with the largest logistics routes and infrastructure projects in the world and under the control of China (the "Belt and Road" Initiative and directly the "Silk Road Economic Belt");

- to create of a system of key logistics points subordinate to China (investing in the development of the infrastructure of the Panama and Suez Canals, as well as the ports of Greece, Italy and a number of Latin American countries);

- active export of capital abroad and the massive purchase of assets of European and American companies, as well as the creation of a network of major investment multinational companies;

- acquisition of major industries in Latin America, North and South Africa to provide the country with resources and energy;

- formation of a parallel system of key world banks ("Asian Infrastructure Investment Bank" (AIIB), "New BRICS Bank"), mutual settlement systems through national currencies with a dominant presence of the renminbi, expansion of Union Pay settlement system;

- promotion of the thesis about a "community of shared future for mankind" to create a new non-systemic unification of countries without concluding formal agreements;

- to create its independent system of scientific research in promising areas (biotechnology, genetic engineering, new forms of matter, etc.) in order to "take leading positions in all key areas of science and technology" and gradually move to mass export of technologies by 2035, not goods;

- progressive development of new weapons, space exploration.

Such a reglobalization model is inherently a change in the globalization vector, i.e., if earlier the idea of liberalization and globalization came from the leading Western countries, then at present China is the leading initiator of these processes. On the other hand, with a change in foreign economic policy, (including transport, energy, financial, etc. infrastructures): 
China seriously revised its domestic economic policy after the global financial crisis of 2008, the country proclaimed the beginning of a policy of focusing on domestic consumption. Faced with the problem of a sharp decline in exports to the crisis-ridden US and EU, China has taken measures to increase household incomes to form the necessary effective demand. This led to the fact that the cost of labor increased sharply, and this ceased to be one of the key factors in the competitive advantage for foreign investment.[16]

TABLE I. ChANGES IN FDI INFLOWS TO CHINA FROM 2016 To 2018[2]

\begin{tabular}{|l|l|l|}
\hline \multicolumn{1}{|c|}{ Year } & \multicolumn{1}{|c|}{ Value } & \multicolumn{1}{c|}{ Change, $\%$} \\
\hline 2018 & -107019758836 & $285.09 \%$ \\
\hline 2017 & -27790987920 & $-166.69 \%$ \\
\hline 2016 & 41674876170 & $-161.2 \%$ \\
\hline
\end{tabular}

According to experts, of the 35 billion dollars of Chinese export losses, 21 billion dollars was redirected to other countries. In the Southeast Asian region, Vietnam, Malaysia, and, to a lesser extent, Indonesia, took advantage of the situation.

\section{B. Vietnamese experience in attracting FDI}

Taking advantage of the changing situation on the global FDI market, the Vietnamese government has taken the path of creating a variety of favorable conditions for attracting more foreign capital. In particular, special economic zones are actively developing, expanding the access of foreign investors to the Vietnamese market (see Fig.1).

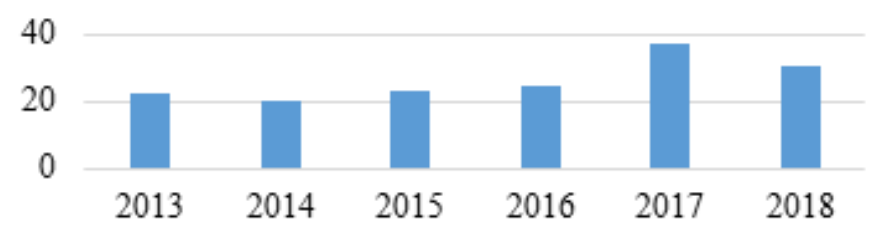

Fig. 1. FDI inflows to Vietnam 2013-2018. (billion, US\$) [5]

With regard to special economic zones, the choice of location for their creation was not accidental. So, the Northern SEZ was created in the immediate vicinity of the VietnameseChinese border, in an area that has historically had developed transport infrastructure connecting both countries. The territory of the zone covers 6 provinces, which is $4.7 \%$ of the territory of Vietnam and $16.6 \%$ of the population.[6]

Within the framework of the functioning of the Northern SEZ, foreign investors are provided with: tax holidays on corporate profits for up to 4 years and after this period a reduced tax rate for another nine years is provided; exemption from import duties on certain types of goods.

Another important advantage of the region is the availability of skilled labor, which distinguishes this region from Central and South Vietnam, where the labor force is more diversified in terms of skill level.[7] The cost of labor is also a serious competitive advantage of Vietnam as a whole, the minimum wage in the country varies between $\$ 100-\$$
128, while in China it is about $\$ 400$, the average salary of industrial workers and managers is $\$ 120-810$, in China - from $1000 \$$.

In total, 64 industrial parks have been created in the territory of the zone, about 800 investment projects are being implemented, the increase in the number of which occurred just in the study period. According to the government's plans, the share of the zone in the country's GDP should reach $29 \%$ by 2020 . To achieve such a serious indicator, the emphasis in the development of the zone is on attracting investors to the oil and gas industry, steel industry, shipbuilding, production of new materials, etc. This predetermined that the zone became in Vietnam the leader in the number of enterprises with foreign and Chinese capital transferred there from China, the headquarters and representative offices of companies such as Chevron (the second integrated US energy company after ExxonMobil) and Bridgestone (Japanese company tire manufacturer) and others that have been active in China.

The central SEZ is different in that it provides foreign investors with less favorable conditions than the northern zone. Tax holidays are provided for 2 years, with a subsequent reduction in corporate income tax rates for 3 years, and exemption from import duties. However, it is attractive in this area that in recent years the largest city in the region, Danang, has become a center for seafood production and the development of the food industry, which has led to a rapid process of urbanization. This attracted foreign investors. IBM (USA), General Electric (USA) and Cisco (USA) are actively involved in the modernization of telecommunication networks in the cities of this SEZ.

The Southern SEZ is the Vietnam's most economically diversified SEZ. It is here that a number of state initiatives are concentrated, the purpose of which is to support the creation of joint projects with foreigners in various fields, and Vietnamese enterprises are ready to implement contracts in almost any field. There was also a good balance between supporting large and small investment projects. For this reason, for example, in recent years, Ho Chi Minh City, in particular, has become a center for technology startups and technology parks.

The favorable conditions created by the Vietnamese government for the placement of FDI aroused the interest of many foreign investors who had to think about transferring capital from China, which became unprofitable. Thus, Wanek Furniture, an affiliate of Ashley Home, the largest US supplier and retailer, has transferred up to $70 \%$ of mattress production from China to Vietnam. Following them, Warren Buffett's Brooks Running company also relocated its production to Vietnam due to U.S. sanctions imposed on China. Also, in September 2019, one of the largest US technology corporations, Apple announced the transfer of $30 \%$ of the company's production to Vietnam, the catalyst of which was the threat of $25 \%$ tariffs on devices, including phones, laptops and tablets. The South Korean manufacturer of medical equipment IM Healthcare also announced the possibility of moving production from the PRC to Vietnam in the event of an escalation of the US-PRC trade conflict. 
At the same time, not only foreign investors prefer to transfer capital from China to Vietnam: a number of Chinese companies also chose to leave the home market in order to maintain their competitive advantages and their position in the US market. Thus, technology companies Lenovo (China), Acer (Taiwan) and Asus (Taiwan) have already announced their intention to move production facilities from China to Vietnam.

Today, Vietnam faces the challenge of finding the optimal balance for the level of participation in the economy of enterprises with foreign and national capital. For almost 20 years, the share of companies with FDI in the country's total exports has been steadily increasing, in 2018 making about $71 \%$ (+ 11\% compared to 2016). Such a situation creates a strong dependence of Vietnam on the flow of foreign investment, and also leads to the gradual crowding out of the market of national small and medium enterprises, which are unable to compete with large foreign companies that are superior to them in their production and marketing capabilities.

\section{Malaysian experience in attracting FDI}

Along with Vietnam, Malaysia seized the opportunity to receive a significant amount of foreign investment. By 2018, the Malaysian economy has already created an attractive business environment for foreign direct investment by pursuing a generally liberal and transparent investment policy characterized by the competitiveness of Malaysian industries, attractive investment incentives from the state, developed infrastructure, and high rates of domestic consumption due to high per capita income and low unemployment.

According to a report by the ASEAN Secretariat, there are 530 free economic zones operating in Malaysia, most of which are state-owned (77\%), but there are also private business zones (23\%).[9] In the SEZs of Malaysia, investors can receive income tax exemption for a period of 10 years, as well as receive a four-year exemption from payment of excise duty, sales tax and service charge. In addition, an exemption has been introduced for foreign manufacturers from payment of export customs duties on goods produced in the territory of SEZ and, subsequently, exported to foreign markets. An additional incentive for the influx of foreign investment into the SEZs of Malaysia was the exemption from import duties on raw materials, semi-finished products, machinery and equipment imported for the organization of production in the zone, or for retail trade.

Another leading competitive advantage of Malaysia is the development of labor resources at a relatively low cost of labor: on the peninsular part of Malaysia, the minimum wage for private workers is approximately $\$ 250$, and in the island states of Sarawak, Sabah and the federal territory of Labuan \$188-216. It is also important to note that in Malaysia there is no single law regulating FDI that describes the general principles and rules of foreign participation in local business.

In addition, by 2018, five economic corridors were created in Malaysia precisely in the areas with the cheapest labor with the goal of maximizing the country's economic potential, narrowing the gap in population income levels and increasing the production of high value-added products in high-tech industries. An equally important task for these corridors was to facilitate the entry of FDI into the region and to stimulate the clustering of the national economy based on its restructuring and integration into the global production chain. Thus, the South Iskandar Economic Corridor, which is favorably distinguished by its geographical proximity to Singapore and has two ports on its territory, has adopted such areas as information technology and biotechnology, industry and electronics, Islamic banks, education and healthcare.[] Konica Minolta, a Japanese holding company, one of the world's leading manufacturers of photocopiers, fax machines, laser printers, medical photo equipment, optical components and measuring equipment, plans to take advantage of this particular economic corridor.[8]

The East Coast Economic Corridor goal is to promote the development of five clusters in the fields of the oil and gas industry, agriculture, tourism and education. However, today the main focus is on exports related to manufacturing, and transforming this vibrant center of trade.

The Sabah Economic Corridor, designed to stimulate the state's economic development and the formation of a center for trade, investment and tourism, industry and agriculture, is known for its cultural heritage and natural resources. This corridor has great potential in the field of services and resource development. Sabah offers foreign investors the opportunity to invest in the petrochemical and gas industries. Along with this, Sabah's agricultural lands, marine resources and forests allow here to develop logging, woodworking, food and biotechnological industries. Sabah accounts for nearly $30 \%$ of Malaysian palm oil production.

The Sarawak Economic Corridor, which should be formed by 2020 as a center for the development of renewable energy sources and attracting energy-intensive industries, has also attracted foreign investors. The Sarawak Corridor is associated with the development of renewable energy sources. The core of the corridor is hydropower resources $(28,000$ megawatts), coal (1.46 billion tons) and natural gas (over a trillion cubic meters).

Another, no less significant for attracting FDI, was the Northern Economic Corridor, and the main vector of its development is set by the high-tech Kulim park, created with the goal of producing high value-added products, developing industrial and agricultural sectors, tourism and logistics. The Northern Economic Corridor has become a leading recipient of foreign capital since the aggravation of US-China trade relations, since it was here that the Malaysian government intensified the development of transport infrastructure (including the transformation of the Penang port into a large transport hub). Preferential conditions for foreign enterprises in the territory of the SEZ and economic corridors, low cost of labor remuneration with a relatively high qualification of the workforce, as well as a developed degree of infrastructure predetermined the attention of foreign capital to placement in Malaysia. For example, Google has moved a significant portion of its motherboard production for the US market from China to Malaysia, and Kerry Logistics Network Ltd., Asia's largest shipping and logistics company based in Hong Kong, 
is currently moving its production lines from China to northern Malaysia.

Another factor affecting the influx of foreign investment into Malaysia is their political affinity with China, due to the participation of Malaysia in the Chinese Belt and Road initiative, namely in the East Coast Railway Line (ECRL) project. It is also necessary to take into account the fact that the Malaysian economy is largely integrated with the Chinese economy: almost $70 \%$ of all Chinese oil imports are carried through the Strait of Malacca, which shares Malaysia with Indonesia, and China also acts as the main exporter of agricultural and technological products of Malaysia. That is what makes it one of the largest foreign investors in Malaysia (see Fig. 2).

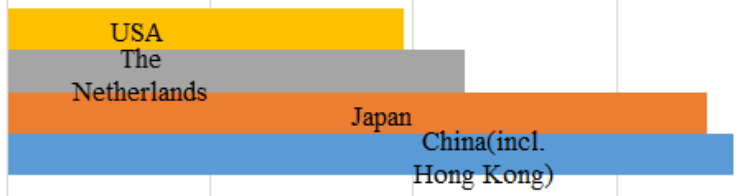

0

20

40

60

80

Fig. 2. Countries with Highest Cumulative FDI in Malaysia in 2018 (billion, US\$) [3]

The change of political elites in Malaysia caused a temporary suspension of construction, as the new Malaysian government insisted on large investment infusions into the Malaysian economy from China and increased exports of Malaysian products to China: China agreed to export palm oil worth nearly $\$ 150$ million from Malaysia as part of a barter deal and Malaysia will receive construction technologies, products from natural resources, as well as civil and defense equipment from China. Mostly, Malaysia managed to achieve the position of a leading recipient of Chinese foreign direct investment, which, at the same time, retains its position in the American market due to the presence of American companies in the development of oil fields in Malaysia. Nonetheless, the Malaysian government is also cautious about accepting Chinese investors because it is reluctant to undergo costly investigations, as well as potential U.S. trade fees for placing Chinese investments trying to circumvent US tariffs.

\section{Indonesian experience in attracting FDI}

Compared to the successful experiences of countries that have received a powerful additional influx of FDI from a change in China's economic agenda, the example of Indonesia seems less successful. The country also tried to integrate into the process of attracting foreign investment, also following the path of creating the SEZ.

Currently, Indonesia has 8 special economic zones located in the provinces of Banten, North Sumatra, Central Sulawesi, North Sulawesi, West Nusa Tenggara, North Maluku, South Sumatra and East Kalimantan. SEZs are created for the development of one particular cluster (for example, petrochemistry, steel production, bauxite processing, chemical production based on coal processing, nickel smelting, etc.).[11] However, most SEZ projects suffer from insufficient infrastructure. One of them was the Tanjung Lesung zone in West Java, focused on tourism development, and the other Sei Mangkei in North Sumatra, whose main specialization is the production of palm oil and natural rubber. An analysis of the current situation showed that there are only two operating plants in the SEI-Mangkay SEZ, and even a minimum of the necessary infrastructure has not yet been created in Tanjungka. In addition, a specific feature of Indonesia's SEZ is a $25 \%$ corporate rate (several times higher than that of regional competitors such as Vietnam and Malaysia), although the government plans a phased reduction to $20 \%$ starting in 2021 .

The President announced the creation of an additional 17 SEZs by 2020 . 10 of the created SEZs will be focused on the development of tourism services, 7 - on the development of the extraction of mineral resources, fisheries, as well as the production of goods with high added value in the engineering and electronic industries.

In 2018, FDI implementation was carried out in the following sectors: mining (1.2 billion US dollars), metallurgy, engineering and electronics ( 0.8 billion US dollars), real estate ( 0.8 billion US dollars), electricity, gas and water (\$0.7 billion), transportation and equipment ( $\$ 0.5$ billion). Contribution to manufacturing was $\$ 3.2$ billion. The main investors in the economy of Indonesia were Singapore (\$ 2.1 billion), Japan ( $\$ 1.4$ billion), China ( $\$ 0.6$ billion), the United States ( $\$ 0.6$ billion), South Korea ( $\$ 0.4$ billion).

Nevertheless, the investment climate in Indonesia does not allow the country to take advantage of the transfer of foreign capital from China: multiple prohibitions on the participation of foreign capital in production, various restrictions, most of which include requirements for special licenses and restrictions on property rights reduce the interest of foreign investors in this country. The most difficult sectors for FDI entry are forestry, tourism, telecommunications, energy, mining, and finance. The main problem for foreign investors in Indonesia remains the practice of restricting FDI in some sectors through a special prohibition list that consolidates the restrictions on FDI by numerous decrees and regulations.

Despite the declared status of an open economy and efforts to attract foreign investment, Indonesia is actively applying both tariff and non-tariff types of protection for its market, including a ban on FDI in micro, small and medium enterprises, a ban on import of automobile and motorcycle tires (except for bulky ones), electric lamps, matches, some types of fabrics, batteries, sheet steel, radio and television receivers, explosives, and some Chinese medicines diet medicine, certain types of agricultural food; quotas and licensing of imports (corn, soybeans, rice, raw sugar, beef, fruits, alcohol-containing drinks), the monopoly of stateowned companies on imports (fuel for vehicles, sea and river vessels, aircraft); the monopoly of the exclusive representative office appointed by the Government of Indonesia (import of fully assembled motorcycles and cars), restriction of checkpoints for certain items of goods, technical barriers (mandatory inclusion of the local component, toughening the certification procedure of imported food, cosmetics, medicines, mandatory use of the Indonesian language when concluding contracts). Among other things, the Indonesian 
government is trying to secure its own share in the use of the country's national resources, arguing that the foreign mining companies operating today (it is important to note that development is carried out solely on the basis of a temporary land use agreement, as foreign investors cannot have ownership in Indonesia) should gradually transfer over a period of 10 years $51 \%$ of the shares to Indonesian investors. This decision caused a negative reaction from six companies with predominant foreign investments, mining in the country PT Vale Indonesia, gold mining companies PT Nusa Hamahera Mineral, PT Kasongan Bumi Kencana and PT Ensbury Kalteng Mining, as well as diamond mining company PT Galuh Kencana. Under the new proposed oil and gas laws, the state's national oil company will have the right to refuse any new contract for the development of oil and gas fields in Indonesia. This decision also reduced Indonesia's attractiveness to foreign investors and provoked a powerful outflow of foreign capital in 2017-2018. (see Fig. 3).

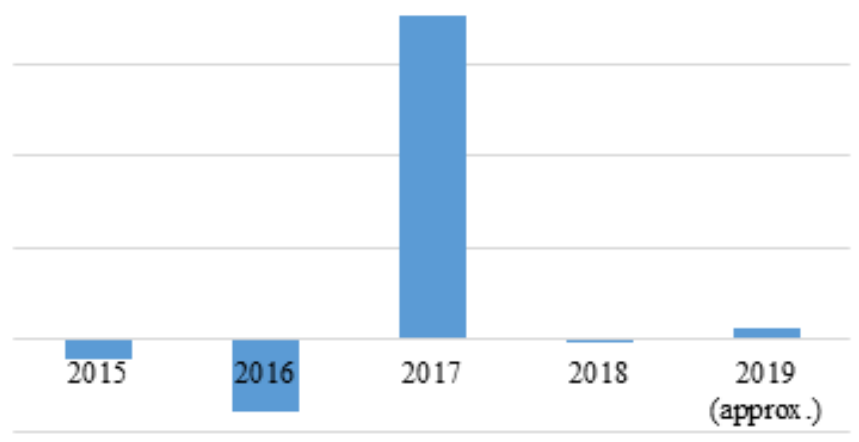

Fig. 3. Indonesian net foreign direct investment inflows in current prices, $\%[15]$

Nevertheless, the Indonesian government allows the presence of foreign investment in the training and development of labor resources and education in Indonesia, which will allow transferring the skills and technologies necessary for their effective participation in the management of foreign companies. As a rule, a company can only hire foreigners to positions that the government considers open to non-Indonesians. It is Indonesia's tough stance on foreign investment that causes an unstable inflow of foreign capital into the country (see Figure), and also deprives Indonesia of the opportunity to attract foreign investment and benefit from the changing environment in the Asian foreign investment market.

\section{CONCLUSION}

The global transformation of international economic relations gives impetus to the emergence of new regional leaders who previously remained in the shadow of larger players. Thus, conceptual transformations within China, as well as changes in the economic and political agenda in the international arena, made it possible for a number of Southeast Asian countries to intensify their development due to more favorable conditions for placing foreign direct investment mainly in export-oriented manufacturing sectors. In this regard, Vietnam and, to a lesser extent, Malaysia are ahead of most other Asian countries because it has always adhered to an export-oriented growth strategy - this is the "secret of success" of these countries. Along with this, Indonesia was not able to respond in a timely manner to the changing landscape, and therefore could not attract international business to its country.

\section{REFERENCES}

[1] W. Tian, M. Yu, F. Zhang, "The exceptional performance of Chinese outward direct investment firms," China Economic Journal, vol. 9(2), 2016, pp. 209-219.

[2] S. Gusarova, "Role of China in the development of trade and FDI cooperation with BRICS countries," China Economic Review, vol. 57, 2016.

[3] H.X. Wu, "Rethinking China's industrialization," Economics explanation of roles of state and government, vol. 75, 2014, pp. 1-236.

[4] D.H. Perkins, "Understanding the slowing growth rate of the People's Republic of China," Asian Development Review, vol. 32(1), 2015, pp. 1-30.

[5] N.A. Nguyen, T. Nguyen, "Foreign direct investment in Vietnam: An overview and analysis," The determinants of spatial distribution across provinces. MPRA Paper 1921, 2007.

[6] D.T. Nguyen, F. Yamauchi, T.D. Nguyen, M. Eiichi, T.T. Pham, T.T. Nguyen, "Labor Productivity and Wage Growth in Vietnam," Vietnam Institute for Economic and Policy Research (VEPR) and Japan International Cooperation Agency (JICA)'s Workshop on 13th September, 2017. Retrieved on 15th September, 2017. Available http://vepr.org.vn/upload/533/fck/files/1_\%20Full\%20ENG_20170912_ 0615pm.pdf.

[7] N.T. Xuan, Y. Xing, "Foreign direct investment and exports," The experiences of Vietnam Econ. Transit., vol. 16(2), 2008, pp. 183-197.

[8] G.M. Kostyunina, V.I. Baronov, "Transboundary Free Economic Zones in Foreign Countries," Journal of MGIMO-University, 2017.

[9] Y.T. Chai, I. Oojuoi Chooi, The Development of Free Industrial Zones The Malaysian Experience, 2009, p. 10.

[10] R. Suyanto, H. Salim, H. Bloch, "Does foreign direct investment lead to productivity spillovers?," Firm level evidence from IndonesiaWorld Development, vol. 37(12), 2009, pp. 1861-1877.

[11] P. Takii, "Do FDI spillovers vary among home economies?," Indonesian manufacturing Journal of Asian Economics, vol. 22(2), 2011, pp. 152163.

[12] S. Elkomy, H. Ingham, R. Read, "Economic and political determinants of the effects of FDI on growth in transition and developing countries," Thunderbird Int. Bus. Rev., vol. 58(4), 2016, pp. 347-362.

[13] C.C. Hoang, "The impact of the World Trade Organization (WTO) regime on foreign direct investment (FDI) flows to Vietnam," J. Mod. Account. Audit., vol. 9(7), 2013, pp. 961-987.

[14] D.T.H. Nguyen, S. Sun, S. Anwar, "A long-run and short-run analysis of the macroeconomic interrelationships in Vietnam Econ," Anal. Policy, vol. 54, 2017, pp. 15-25.

[15] Central Bank of Indonesia. Economic and financial data for Indonesia(2017-2019).

[16] N. Salike, "Role of human capital on regional distribution of FDI in China," New evidences. China Econ. Rev., vol. 37, 2016, pp. 66-84.

[17] United Nations Conference on Trade and Development (UNCTAD). (2016). World investment report 2016: FDI from developing and transition economies: Implications for development. United Nations, New York.

[18] International Energy Agency South East Asia Energy Outlook: world energy outlook special report. OECD/IEA; 2013-2017.

[19] United Nations Environment Programme (UNEP). Towards a green economy: pathways to sustainable development and poverty eradication — a synthesis for policy makers UNEP, Nairobi (2011). 
[20] United Nations Economic and Social Commission for the Asia Pacific (UNESCAP) Greening growth in Asia and the Pacific. UNESCAP,
Bangkok (2008). 